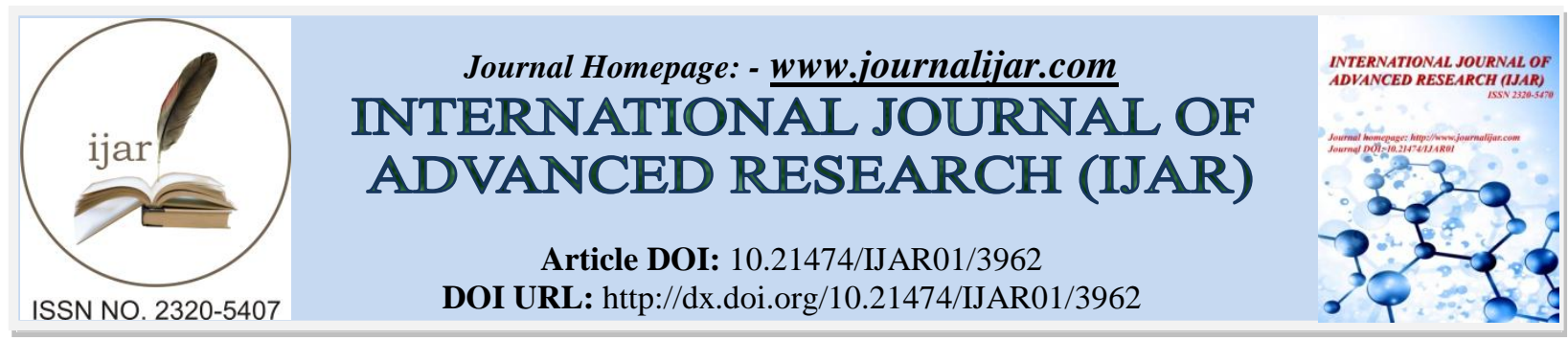

RESEARCH ARTICLE

\title{
LIVED EXPERIENCE OF PATIENTS UNDERGOING HEMODIALYSIS.
}

\section{Ms. Saroj L Shah ${ }^{1}$ and Mrs. K. Chithra ${ }^{2}$.}

1. M.Sc. Nursing final year, Teerthanker Mahaveer College of Nursing, TMU, Moradabad, U. P.

2. Assistant Professor, Teerthanker Mahaveer College of Nursing, TMU, Moradabad, U. P.

\section{Manuscript Info}

Manuscript History

Received: 10 February 2017

Final Accepted: 01 March 2017

Published: April 2017

Key words:-

lived experiences,, hemodialysis.

\begin{abstract}
Background: Chronic kidney disease is a chronic illness, patients had to take long term treatment and depend on hemodialysis for their whole life. They suffer from physical problems, emotional problems and financial problems. Objectives: To understand the lived experience of patients undergoing hemodialysis. Method: The reviews were on the patients undergoing for hemodialysis by using phenomenological design and semi structured interview was done to collect the data from the patients. Data was coded by using thematic analysis were derived from them. Keyword searches of EBSCO, DELNET \& Pub medMedline databases, found 14 reviews selected 9 reviews for this study based on the lived experiences of patients undergoing hemodialysis. The 3 reviews are not based on the lived experiences of hemodialysis and in 2 review based on same article but there is no time duration of semi structured interview so those study were not included in the review. Results: Qualitative reviews ( $\mathrm{n}=9$ ) on lived experiences of patient undergoing hemodialysis.After analysing the results three themes has emerged out acceptance of illness, emotional distress and dependent on hemodialysis for living. Conclusion: Patients undergoing hemodialysis emerged out with lot of problems where they unaccepted the experiences and feeling of burden in society and thinks hemodialysis is a part of life due to lack of support and guidance From these reviews it helps nurses to utilize these information and guide patients to provide positive reinforcement for their future living.
\end{abstract}

Copy Right, IJAR, 2017,. All rights reserved.

\section{Introduction:-}

Chronic kidney disease (CKD) is the worldwide health problem. According to World Health Organization Global burden of disease project, diseases of the kidney and urinary tract were contribute to global burden with approximately 850,000 deaths every year and $115,010,107$ cause of disability. CKD is the $12^{\text {th }}$ leading cause of death and $17^{\text {th }}$ cause of disability.

In past, chronic glomerulonephritis was the most common cause of chronic renal failure, but today, diabetes mellitus and hypertension had taken center stage in the causation of ESRD which together account for almost $60 \%$ of hemodialysis patients with these causes. 
Patients with renal failure have been protectively treated in early stage of the disease and eventually they need a hemodialysis and renal transplantation for securing and extending their life. Hemodialysis is the most common protective treatment process in which the toxic nitrogenous substances, water and electrolytes are refined by hemodialysis unit in hemodialysis centers two or three times a week.

Patients with ESRD faced many challenges due to their disease condition which may leave them feeling fatigued and depressed (Theofilou, 2011, 2012). There body image get affected by fistula or grafting for dialysis access. Economically they get affected by the high cost of weekly treatments for hemodialysis and sometime admission to the emergency department due to the complications. Relationships and independency are also threatened (Karamanidou, Theofilou, Ginieri-Coccossis, Synodinou, \& Papadimitriou, 2009; Theofilou, 2011).

Nurses and health professionals need to understand the lived experiences of patients on hemodialysis to respond these physical, psychological, emotional, and spiritual changes. By gaining these insights, health professionals can develop appropriate nursing care and improve quality of care (Polaschek, 2003).

Thus, the purpose of this narrative review is to explore the lived experience of Chronic Kidney Disease and ESRD patients on routine hemodialysis treatments from their own perspectives.

\section{Methods:-}

\section{Search Strategy Methods}

An electronic search of articles published in various journals till January 2016 was conducted. Search was bounded to only English language. The database search done was Pub med- Medline, EBSCO and DELNET. Articles containing following key search terms were retrieved.

\section{Types of studies:}

Qualitative studies with designs: Phenomenological designs, descriptive and exploratory design.

\section{Type of participants:}

Patients undergoing hemodialysis more than one year.

\section{Settings:}

Hospitals, health care centers. 


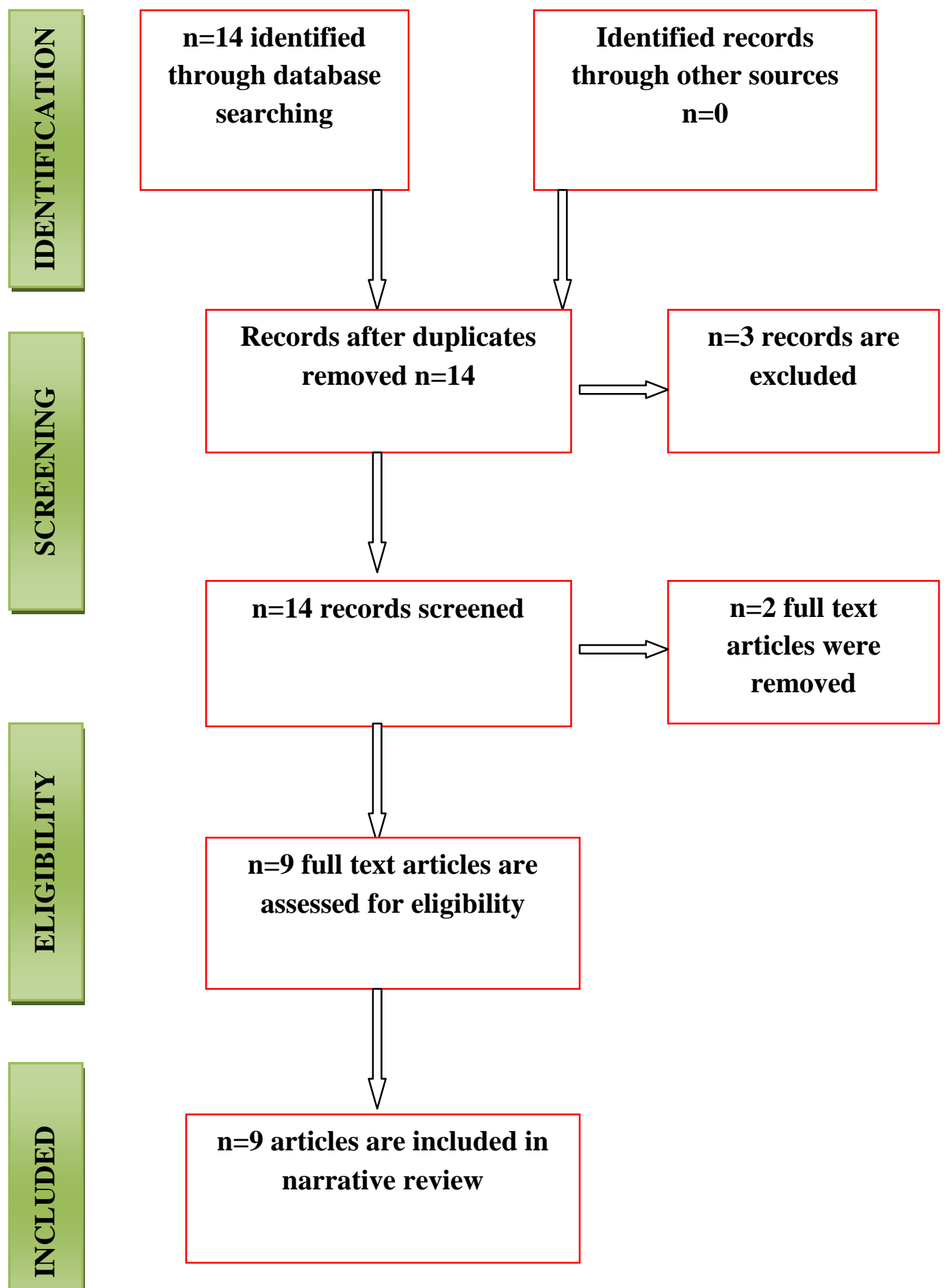

Figure 1:- PRISMA flow chart on narrative review. 


\section{Result:-}

The review identifies two groups of qualitative studies on lived experiences of hemodialysis.

1. Studies that focused on lived experiences of patient undergoing hemodialysis ( $n=6$, summarised in table 1) .First study focused on the acceptance of illness, second, third and fifth highlighted on the negative impact of illness in their live, fourth revealed emotional distress need of support, further study sixth focused on hemodialysis equal as life.

2. Studies differentiate between stress and life experience undergoing hemodialysis $(n=3$, summarised in table 2$)$. First study conducted in India, Bangalore (2014) explored on the psychological emotional stress other two, one based that life without hemodialysis unaccepted conducted in Tehran (2010), other on sense of loss of life physically, mentally, socially.

3. After analysing the results three themes has emerged out acceptance of illness, emotional distress and dependent on hemodialysis for living.

\section{Acceptance:-}

In one review it reveals that patients have positive outlook towards the hemodialysis as patients psychologically and mentally changed they manage in the dietary habits and life style and accepted the changes in their ongoing treatment of hemodialysis.

"I like coming to treatments and leaving here feeling better than I did before... Dialysis is definitely a good thing for me."

"I have learn not to drink lot of salty stuffs, and not to eat more stuff that damage the body, and I learned how to take care of myself."

\section{Emotional Distress:-}

Mostly patient suffering from the illness feeling of isolation from society, burden for family members, feeling neglected, physical limitations, fatigue not able to perform daily activities, unemployment and lot of challenges faced during the illness and difficult to survive with the severe problems facing due to hemodialysis ongoing treatment .

"Ifeel, as if I am dead, my mind is not there with me, no interest to live... I can no longer feel or enjoy anything."

"Neighbors and relatives stopped talking to us ; they are scared that we may ask for money from them."

"I cannot lie down or sleep due to severe breathlessness and not able to perform my daily activities due to fear of fistula".

Dependent:- In some reviews patients undergoing hemodialysis feels that life without hemodialysis is lifeless they depend on hemodialysis for their living which bring hope of living, feels hemodialysis is a part of their life for surviving.

"This is our life, all of it is dialysis, if we don't come here for one day it is not clear what will happen to us, surely we die, it is more important than our women and children". 
Table 1:- Summary of study characteristics: lived experience patient undergoing hemodialysis

\begin{tabular}{|c|c|c|c|c|c|c|c|c|}
\hline S.NO. & $\begin{array}{l}\text { PROBLEM } \\
\text { STATEMEN } \\
\text { T/AUTHOR }\end{array}$ & $\begin{array}{l}\text { PLACE } \\
\text { OF } \\
\text { RESEAR } \\
\text { CH \& } \\
\text { YEAR }\end{array}$ & $\begin{array}{l}\text { RESEARC } \\
\text { H } \\
\text { OBJECTIV } \\
\text { E }\end{array}$ & $\begin{array}{l}\text { VARIAB } \\
\text { LES }\end{array}$ & $\begin{array}{l}\text { TOOL } \\
\text { S }\end{array}$ & $\begin{array}{l}\text { TIME } \\
\text { DURAT } \\
\text { ION }\end{array}$ & $\begin{array}{l}\text { OUTCO } \\
\text { MES }\end{array}$ & $\begin{array}{l}\text { REMA } \\
\text { RK }\end{array}$ \\
\hline 1. & $\begin{array}{l}\text { A qualitative } \\
\text { study on- What } \\
\text { Is The Lived } \\
\text { Experience Of } \\
\text { The Client } \\
\text { With End } \\
\text { Stage Renal } \\
\text { Disease On } \\
\text { Hemodialysis. } \\
\text { Diane Scaife }\end{array}$ & $\begin{array}{l}\text { United } \\
\text { States } \\
\text { midwester } \\
\mathrm{n}, 2006\end{array}$ & $\begin{array}{l}\text { To } \\
\text { understand } \\
\text { the lived } \\
\text { experience } \\
\text { of the client } \\
\text { with end } \\
\text { stage renal } \\
\text { disease on } \\
\text { hemodialysi } \\
\text { s. }\end{array}$ & $\begin{array}{l}\text { Lived } \\
\text { experienc } \\
\mathrm{e} \text { of the } \\
\text { client }\end{array}$ & $\begin{array}{l}\text { Semi } \\
\text { structur } \\
\text { ed } \\
\text { intervie } \\
\text { w }\end{array}$ & $\begin{array}{l}30 \text { to } 40 \\
\text { min. }\end{array}$ & $\begin{array}{l}\text { The } \\
\text { outcome } \\
\text { of this } \\
\text { study is } \\
\text { acceptan } \\
\text { ce of } \\
\text { illness in } \\
\text { them. }\end{array}$ & $\begin{array}{l}\text { The } \\
\text { sample } \\
\text { size is } \\
\text { too } \\
\text { small. } \\
\text { Other } \\
\text { that in } \\
\text { this } \\
\text { study it } \\
\text { only } \\
\text { include } \\
\text { the } \\
\text { patient } \\
\text { with } \\
\text { end } \\
\text { stage } \\
\text { renal } \\
\text { disease }\end{array}$ \\
\hline 2. & $\begin{array}{l}\text { A Qualitative } \\
\text { Research on } \\
\text { the Experience } \\
\text { of } \\
\text { Hemodialysis } \\
\text { in South } \\
\text { Karnataka: } \\
\text { Lived } \\
\text { Experience of } \\
\text { Persons } \\
\text { undergoing } \\
\text { Hemodialysis } \\
\text { Blessy Prabha } \\
\text { Valsaraj, } \\
\text { Shripathy M } \\
\text { Bhatt, } \\
\text { Ravindra } \\
\text { Prabhu, Dinesh } \\
\text { N. }\end{array}$ & $\begin{array}{l}\text { Kasturba } \\
\text { Hospital } \\
\text { South } \\
\text { Karnataka } \\
\text { December } \\
2011 \text { to } \\
\text { December } \\
2012\end{array}$ & $\begin{array}{l}\text { To explore } \\
\text { the lived } \\
\text { experiences } \\
\text { of person } \\
\text { undergoing } \\
\text { hemodialysi } \\
\text { s. }\end{array}$ & $\begin{array}{l}\text { Lived } \\
\text { experienc } \\
\mathrm{e} \quad \text { of } \\
\text { persons } \\
\text { undergoin } \\
\mathrm{g} \\
\text { hemodialy } \\
\text { sis. }\end{array}$ & $\begin{array}{l}\text { Semi } \\
\text { structur } \\
\text { ed } \\
\text { intervie } \\
\text { w }\end{array}$ & $\begin{array}{l}50 \text { to } 60 \\
\text { minutes }\end{array}$ & $\begin{array}{l}\text { In this } \\
\text { study it } \\
\text { revealed } \\
\text { that } \\
\text { person is } \\
\text { having } \\
\text { negativit } \\
\text { y } \\
\text { towards } \\
\text { their } \\
\text { illness } \\
\text { and } \\
\text { treatment } \\
\text {. }\end{array}$ & $\begin{array}{l}\text { In this } \\
\text { study } \\
\text { researc } \\
\text { her } \\
\text { unable } \\
\text { to } \\
\text { underst } \\
\text { and } \\
\text { respon } \\
\text { dents } \\
\text { and } \\
\text { done } \\
\text { the } \\
\text { intervi } \\
\text { ew two } \\
\text { times. }\end{array}$ \\
\hline 3. & $\begin{array}{l}\text { Undergoing } \\
\text { Hemodialysis: } \\
\text { A Qualitative } \\
\text { Study to } \\
\text { Investigate the } \\
\text { Lived } \\
\text { Experiences of } \\
\text { Patients } \\
\text { Paraskevi } \\
\text { Theofilou, }\end{array}$ & $\begin{array}{l}\text { Greece } \\
2009\end{array}$ & $\begin{array}{l}\text { To } \\
\text { investigate } \\
\text { the lived } \\
\text { experiences } \\
\text { of } \\
\text { hemodialysi } \\
\text { s patients. }\end{array}$ & $\begin{array}{l}\text { Lived } \\
\text { experienc } \\
\text { es of } \\
\text { patients } \\
\text { undergoin } \\
\mathrm{g} \\
\text { hemodialy } \\
\text { sis }\end{array}$ & $\begin{array}{l}\text { Semi } \\
\text { structur } \\
\text { ed } \\
\text { intervie } \\
\text { w }\end{array}$ & $\begin{array}{l}50 \\
\text { minutes }\end{array}$ & $\begin{array}{l}\text { In this } \\
\text { study it } \\
\text { revealed } \\
\text { that } \\
\text { patients } \\
\text { have } \\
\text { negative } \\
\text { impact in } \\
\text { their } \\
\text { social } \\
\text { health }\end{array}$ & $\begin{array}{l}\text { In this } \\
\text { study } \\
\text { not } \\
\text { define } \\
\text { sampli } \\
\text { ng } \\
\text { techniq } \\
\text { ue, the } \\
\text { exclusi } \\
\text { on } \\
\text { criteria }\end{array}$ \\
\hline
\end{tabular}




\begin{tabular}{|c|c|c|c|c|c|c|c|c|}
\hline & $\begin{array}{l}\text { Clairy } \\
\text { Synodinoua, } \\
\text { Helen } \\
\text { Panagiotakic }\end{array}$ & & & & & & $\begin{array}{l}\text { and daily } \\
\text { lives. }\end{array}$ & $\begin{array}{l}\text { and at } \\
\text { what } \\
\text { duratio } \\
\mathrm{n} \text { they } \\
\text { have } \\
\text { collect } \\
\text { ed the } \\
\text { data. }\end{array}$ \\
\hline 4. & $\begin{array}{l}\text { Starting on } \\
\text { hemodialysis: } \\
\text { A qualitative } \\
\text { study to } \\
\text { explore the } \\
\text { experience } \\
\text { and needs of } \\
\text { incident } \\
\text { patients } \\
\text { Alden } \\
\text { Yuanhong Lai, } \\
\text { Angela Ping } \\
\text { Ping Loh, } \\
\text { Nandakumar } \\
\text { Mooppil, } \\
\text { Deby Sarojiuy } \\
\text { Pala Krishnan } \\
\text { and Konstadina } \\
\text { Griva }\end{array}$ & $\begin{array}{l}\text { Singapore } \\
, 2011\end{array}$ & $\begin{array}{l}\text { To explore } \\
\text { the lived } \\
\text { experience } \\
\text { of } \\
\text { hemodialysi } \\
\text { s patient. }\end{array}$ & $\begin{array}{l}\text { Experienc } \\
\text { e and need } \\
\text { of } \\
\text { patients. }\end{array}$ & $\begin{array}{l}\text { Semi } \\
\text { structur } \\
\text { e } \\
\text { intervie } \\
\text { w }\end{array}$ & $\begin{array}{l}35 \text { to } 50 \\
\text { minutes }\end{array}$ & $\begin{array}{l}\text { In this } \\
\text { study it } \\
\text { revealed } \\
\text { the } \\
\text { patients } \\
\text { is having } \\
\text { more } \\
\text { emotiona } \\
\text { 1 distress } \\
\text { after } \\
\text { knowing } \\
\text { about } \\
\text { illness } \\
\text { and need } \\
\text { of } \\
\text { informati } \\
\text { on and } \\
\text { knowled } \\
\text { ge } \\
\text { regardin } \\
\text { g illness. }\end{array}$ & $\begin{array}{l}\text { In this } \\
\text { study it } \\
\text { discuss } \\
\text { es the } \\
\text { partici } \\
\text { pants } \\
\text { with } \\
\text { diabete } \\
\text { s and } \\
\text { central } \\
\text { venous } \\
\text { cathete } \\
\text { r but in } \\
\text { study it } \\
\text { not } \\
\text { mentio } \\
\text { ns the } \\
\text { statisti } \\
\text { cs } \\
\text { proble } \\
\text { m with } \\
\text { this } \\
\text { conditi } \\
\text { on. }\end{array}$ \\
\hline 5. & $\begin{array}{l}\text { Lived } \\
\text { Experience of } \\
\text { Patients } \\
\text { Undergoing } \\
\text { Hemodialysis: } \\
\text { Quality of Life } \\
\text { Perspective } \\
\text { Mrs. Rohini. , } \\
\text { Dr. Punitha. V. } \\
\text { Ezhilarasu }\end{array}$ & $\begin{array}{l}\text { Ernakula } \\
\mathrm{m} \text { district } \\
\text { in Kerala , } \\
2014\end{array}$ & $\begin{array}{l}\text { To explore } \\
\text { the lived } \\
\text { experience } \\
\text { of quality of } \\
\text { life among } \\
\text { patients } \\
\text { undergoing } \\
\text { hemodialysi } \\
\text { s. }\end{array}$ & $\begin{array}{l}\text { Lived } \\
\text { experienc } \\
\mathrm{e} \quad \text { of } \\
\text { patients } \\
\text { undergoin } \\
\mathrm{g} \\
\text { hemodialy } \\
\text { sis }\end{array}$ & $\begin{array}{l}\text { Semi } \\
\text { structur } \\
\text { ed } \\
\text { intervie } \\
\text { w }\end{array}$ & $\begin{array}{l}15-20 \\
\text { minutes }\end{array}$ & $\begin{array}{l}\text { In this } \\
\text { study it } \\
\text { revealed } \\
\text { the } \\
\text { negative } \\
\text { experien } \\
\text { ce } \\
\text { towards } \\
\text { their } \\
\text { illness } \\
\text { and need } \\
\text { of } \\
\text { knowled } \\
\text { ge } \\
\text { regardin } \\
\text { g their } \\
\text { treatment } \\
\text { and } \\
\text { illness. }\end{array}$ & $\begin{array}{l}\text { Inclusi } \\
\text { on } \\
\text { criteria } \\
\text { are not } \\
\text { mentio } \\
\mathrm{n} \text { and } \\
\text { also } \\
\text { age } \\
\text { limitati } \\
\text { on is } \\
\text { not } \\
\text { present } \\
\text { in this } \\
\text { study. }\end{array}$ \\
\hline 6. & $\begin{array}{l}\text { The Lived } \\
\text { Experience of } \\
\text { Patients' with } \\
\text { End Stage } \\
\text { Renal Disease }\end{array}$ & $\begin{array}{l}\text { Ministry } \\
\text { of Health } \\
\text { hospitals, } \\
2014\end{array}$ & $\begin{array}{l}\text { To describe } \\
\text { the lived } \\
\text { experiences } \\
\text { of patients } \\
\text { with end }\end{array}$ & $\begin{array}{l}\text { Lived } \\
\text { experienc } \\
\text { es of } \\
\text { patients } \\
\text { with } \\
\end{array}$ & $\begin{array}{l}\text { In depth } \\
\text { semi } \\
\text { structur } \\
\text { ed } \\
\text { intervie }\end{array}$ & $60 \mathrm{~min}$. & $\begin{array}{l}\text { In this } \\
\text { study it } \\
\text { reveals } \\
\text { that with } \\
\text { hemodial }\end{array}$ & $\begin{array}{l}\text { In this } \\
\text { study it } \\
\text { not } \\
\text { mentio } \\
\mathrm{n} \quad \text { at }\end{array}$ \\
\hline
\end{tabular}




\begin{tabular}{|c|c|c|c|c|c|}
\hline $\begin{array}{l}\text { on } \\
\text { Hemodialysis: } \\
\text { A } \\
\text { Phenomenolog } \\
\text { ical Study } \\
\text { Dr. Suhair Al- } \\
\text { Ghabeesh, Dr. } \\
\text { Khaled } \\
\text { Suleiman }\end{array}$ & \begin{tabular}{|l} 
stage renal \\
disease on \\
hemodialysi \\
s treatment.
\end{tabular} & ESRD & $\mathrm{W}$ & $\begin{array}{l}\text { ysis is } \\
\text { part } \\
\text { which } \\
\text { equitable } \\
\text { to their } \\
\text { lives. }\end{array}$ & $\begin{array}{l}\text { which } \\
\text { duratio } \\
\mathrm{n} \text { the } \\
\text { researc } \\
\text { her } \\
\text { collect } \\
\text { ed the } \\
\text { data. }\end{array}$ \\
\hline
\end{tabular}

Table 2:- Summary of Study Characteristics Differentiate Between Stress and Life Undergoing Hemodialysis

\begin{tabular}{|c|c|c|c|c|c|c|c|c|}
\hline $\begin{array}{l}\text { S.N } \\
\text { O }\end{array}$ & $\begin{array}{l}\text { PROBLEM } \\
\text { STATEMENT/AU } \\
\text { THOR }\end{array}$ & $\begin{array}{l}\text { PLACE } \\
\text { OF } \\
\text { RESEAR } \\
\text { CH \& } \\
\text { YEAR }\end{array}$ & $\begin{array}{l}\text { OBJECTI } \\
\text { VES }\end{array}$ & $\begin{array}{l}\text { RESEAR } \\
\text { CH } \\
\text { VARIAB } \\
\text { LE }\end{array}$ & $\begin{array}{l}\text { TOOL } \\
\text { S }\end{array}$ & $\begin{array}{l}\text { TIME } \\
\text { DURATI } \\
\text { ON }\end{array}$ & $\begin{array}{l}\text { OUTCO } \\
\text { MES }\end{array}$ & $\begin{array}{l}\text { REMAR } \\
\text { K }\end{array}$ \\
\hline 1. & $\begin{array}{l}\text { Understanding the } \\
\text { experience of stress } \\
\text { on initiation of } \\
\text { hemodialysis :A } \\
\text { phenomenological } \\
\text { study } \\
\text { Sonali Tarachand } \\
\text { Jadhav, Premila } \\
\text { Lee }\end{array}$ & $\begin{array}{l}\text { Two } \\
\text { private } \\
\text { hospitals } \\
\text { in } \\
\text { Bangalor } \\
\text { e , India, } \\
2014\end{array}$ & $\begin{array}{l}\text { To identify } \\
\text { the } \\
\text { stressors } \\
\text { experience } \\
\text { d by the } \\
\text { patient } \\
\text { with CKD } \\
\text { undergoing } \\
\text { hemodialys } \\
\text { is. }\end{array}$ & $\begin{array}{l}\text { Experienc } \\
\text { e of stress } \\
\text { on } \\
\text { initiation } \\
\text { of } \\
\text { hemodial } \\
\text { ysis }\end{array}$ & $\begin{array}{l}\text { Semi } \\
\text { structur } \\
\text { e } \\
\text { intervie } \\
\mathrm{w}\end{array}$ & $\begin{array}{l}30 \text { to } 60 \\
\text { minutes }\end{array}$ & $\begin{array}{l}\text { In this } \\
\text { study it } \\
\text { revealed } \\
\text { that most } \\
\text { of the } \\
\text { adult's } \\
\text { patients } \\
\text { suffered } \\
\text { from the } \\
\text { psycholog } \\
\text { ical and } \\
\text { socio } \\
\text { economic } \\
\text { stress. }\end{array}$ & $\begin{array}{l}\text { A study } \\
\text { should } \\
\text { include } \\
\text { the } \\
\text { patient } \\
\text { with } \\
\text { uremia, } \\
\text { hyerkale } \\
\text { mia } \\
\text { undergoin } \\
\text { g } \\
\text { hemodial } \\
\text { ysis. } \\
\text { Other it } \\
\text { can take } \\
\text { the } \\
\text { patient } \\
\text { experienc } \\
\text { e more } \\
\text { than a } \\
\text { year } \\
\text { rather } \\
\text { than } 6 \\
\text { year. }\end{array}$ \\
\hline 2. & $\begin{array}{lr}\text { Life } & \text { with } \\
\text { hemodialysis } & \text { unit: } \\
\text { A } & \\
\text { phenomenological } \\
\text { study } \\
\text { Fateme } & \\
\text { Sabet, } & \text { Alirezaii } \\
\text { Nikbakht Nasrabadi } \\
\text { Kahid } \quad \text { Karami } \\
\text { Kabir }\end{array}$ & $\begin{array}{l}\text { Ekbatan } \\
\text { Universit } \\
\text { y } \\
\text { Hospital } \\
\text { of } \\
\text { Hamedan } \\
\text { and } \\
\text { Shohaday } \\
\text { e Yaft } \\
\text { Abad } \\
\text { Hospital } \\
\text { of } \\
\text { Tehran, } \\
\text { 2010 }\end{array}$ & $\begin{array}{l}\text { To } \\
\text { understand } \\
\text { better } \\
\text { about } \\
\text { patients } \\
\text { life with } \\
\text { hemodialys } \\
\text { is unit }\end{array}$ & $\begin{array}{l}\text { Life with } \\
\text { hemodial } \\
\text { ysis unit. }\end{array}$ & $\begin{array}{l}\text { In } \\
\text { depth } \\
\text { and } \\
\text { semi } \\
\text { structur } \\
\text { ed } \\
\text { intervie } \\
\text { ws }\end{array}$ & $\begin{array}{l}40 \text { to } 60 \\
\text { minutes }\end{array}$ & $\begin{array}{l}\text { In this } \\
\text { study it } \\
\text { reveals } \\
\text { that life } \\
\text { without } \\
\text { hemodialy } \\
\text { sis is } \\
\text { impossibl } \\
\text { e to } \\
\text { survive. }\end{array}$ & $\begin{array}{l}\text { In this } \\
\text { study it } \\
\text { did not } \\
\text { explain } \\
\text { when } \\
\text { they have } \\
\text { collected } \\
\text { data from } \\
\text { patient in } \\
\text { unit or } \\
\text { after } \\
\text { dialysis. }\end{array}$ \\
\hline
\end{tabular}




\begin{tabular}{|c|c|c|c|c|c|c|c|c|}
\hline 3. & $\begin{array}{l}\text { A 'lost life': } \\
\text { coming to } \\
\text { terms with } \\
\text { hemodialysis } \\
\text { Susan } \\
\text { Monaro, } \\
\text { Glenn Stewart } \\
\text { and Janice } \\
\text { Gullick }\end{array}$ & $\begin{array}{l}\text { Sydney } \\
2008- \\
2010\end{array}$ & $\begin{array}{l}\text { To describe } \\
\text { the essence } \\
\text { of the lived } \\
\text { experiences } \\
\text { of patients } \\
\text { and families } \\
\text { in the early } \\
\text { phase of long } \\
\text { term } \\
\text { hemodialysis } \\
\text { therapy. }\end{array}$ & $\begin{array}{l}\text { Lived } \\
\text { experiences } \\
\text { of patients } \\
\text { and family }\end{array}$ & $\begin{array}{l}\text { Semi } \\
\text { structure } \\
\text { interview }\end{array}$ & $\begin{array}{l}26-72 \\
\text { min. }\end{array}$ & $\begin{array}{l}\text { In this study } \\
\text { it revealed } \\
\text { that sense of } \\
\text { loss they } \\
\text { perceive } \\
\text { from } \\
\text { socially, } \\
\text { mentally or } \\
\text { physically } \\
\text { lost all the } \\
\text { pleasure } \\
\text { happiness } \\
\text { due to their } \\
\text { illness. }\end{array}$ & $\begin{array}{l}\text { In this study } \\
\text { in most of } \\
\text { the } \\
\text { participants } \\
\text { both } \\
\text { families and } \\
\text { patient were } \\
\text { not } \\
\text { interviewed. } \\
\text { They take } \\
\text { interview of } \\
\text { patient or } \\
\text { either } \\
\text { family or } \\
\text { also no } \\
\text { exclusion } \\
\text { criteria are } \\
\text { given. }\end{array}$ \\
\hline
\end{tabular}

\section{Discussion:-}

The qualitative studies of patients undergoing hemodialysis, mostly the research has been conducted in foreign countries: United States of America, Greece, Taiwan, Saudi Arabia and in India one study conducted in south Karnataka kasturba hospital.

This article observed that various themes emerged out acceptance, emotional distress and dependent. Some patients had a positive outlook towards it, others feel that hemodialysis psychologically and socially disturbed and which adhere their daily living and also suffer from deep pain, and others thought hemodialysis is the part of daily living for survival.

One study compared conducted this meta-synthesis analyzed and synthesized findings from qualitative studies of lived experiences of patients on hemodialysis. Four themes emerged as a result of synthesizing findings of the studies: having a physical shackle in life, feeling mental and emotional distress, relying on a hemodialysis machine, and dealing with problems. The themes of having a physical shackle in life and mental and emotional distress have a strong relationship.

\section{Implications:-}

Patients on hemodialysis have many difficulties and sufferings due to their illness and hemodialysis therapy. Individual and social aspects of their life, as well as physical and mental emotional problems, should be considered and understood by nurses and significant others. These problems should be solved so patients may achieve optimum health status and the balance of physical and psychological aspects of their overall life as well as individual and social life and to develop positivity towards their lives.

More studies should be conduct on lived experiences in India to understand more insights and to explore their sufferings which helps much more for health professionals to educate them regarding illness and reduce negative aspects of living.

\section{Conclusion:-}

The review makes an important contribution to understand the lived experiences of patients undergoing for hemodialysis and its describes in the patients perspectives that Patients on hemodialysis have some positivity, difficulties and sufferings due to their illness and hemodialysis therapy. 
These problems should be solved so patients may achieve optimum health status and the balance of physical and psychological aspects of their overall life as well as individual and social life and to develop positivity towards their lives.

In future more studies should be conduct on lived experiences of patients undergoing hemodialysis to understand their insights and to explore their sufferings which helps much more for health professionals to educate them regarding illness and reduce the negative aspects of living.

\section{Acknowledgement:-}

I would like to thank to my management of Teerthanker Mahaveer University and Teerthanker Mahaveer College of Nursing Principal Prof. Dr. N.V Munninarayanappa and Assistant Professor Mrs. K. Chithra for helping me to prepare an article and had a great experience of it.

\section{Reference:-}

1. Bayhakki, Hatthakit, U. (2012). Lived experiences of patients on hemodialysis: A metasynthesis. Nephrology Nursing Journal, 39(4), pp.295-304.

2. Ghabeesh, -AL, S., Suleiman, K. (2014). The lived experience of patients with end stage renal disease on hemodialysis: A phenomenological study. International Journal of Medicine Sciences, 47(1), pp. 1423-1429.

3. Jadhav, S.T, Lee, P. (2014). Understanding the experience of stress on initiation of haemodialysis. International Journal Nursing, 3(1), pp.11-19.

4. Kidner, A. (1999). The lived experiences of persons dependent on hemodialysis. Master Theses. Paper 524.

5. Lai, A.Y., Loh, A.P., Mooppil, N., Krishnan, D.S., Griva, K.(2012). Starting on haemodialysis: A qualitative study to explore the experience and needs of incident patient. Psychology Health \& Medicine, 17(6), pp. 674684.

6. Monaro,S., Stewart, Glenn, Gullick, J. (2014). A'lost life': Coming to terms with hemodialysis. Journal of Clinical Nursing, 23, pp. 3262-3273.

7. Rohini, T., Punitha, E.V. (2016). Lived experiences of patients undergoing hemodialysis: Quality of perspective. The International Journal of Indian Psychology, 3(2), pp. 148-155.

8. Sabet, P., Nasrabadi, Kabir, K. (2011). Life with hemodialysis unit: A phenomenological study. Iranian Journal of Critical Care Nursing Summer, 4(2), pp. 59-66.

9. Scaife, D. (2006). What is the lived experience of the client with end stage renal disease on hemodialysis? Theses \& Dessertations. Paper 1382.

10. Sumintha, C. , Sumintha, M.T. (2014). Lived experiences of individuals with chronic renal failure undergoing hemodialysis in selected hospital. International Journal of Scientific and Research Publication,4(11), pp. 1-7.

11. Theofilou, P., Synodinou, C., Panagiotaki, H. (2013). Undergoing haemodialysis: A qualitative study to investigate the lived experiences of patients. European Journal of Psychology, 9(1), pp. 19-32.

12. Valsaraj, Bhat, M., Prabhu, Dinesh, N. (2014). A qualitative research on the experience of haemodialysis in south Karnataka: Lived experience of persons undergoing hemodialysis. Journal of Krishna Institute of Medical Science University, 3(2),pp. 90-100. 